\title{
How children construct literacy: Piagetian perspective
}

\section{Ferhat Ensar}

Department of Turkish Education, Yildiz Technical University, Esenler, Istanbul, Turkey

\section{Email address:}

fensar@yildiz.edu.tr

\section{To cite this article:}

Ferhat Ensar. How Children Construct Literacy: Piagetian Perspective. International Journal of Secondary Education. Vol. 2, No. 2, 2014, pp. 34-39. doi: 10.11648/j.ijsedu.20140202.12

\begin{abstract}
For centuries, educators have assumed that children acquire knowledge by internalizing it form the environment. It was not until the 1970's that the researchers begun to study about the nature of children's reading and writing systems. Psychologist wondered how children come to understand what literacy is, what functions children believed literacy served in their lives, and how children made use of literacy. This paper tries to answer these questions based on the Piagetian perspective.
\end{abstract}

Keywords: Literacy, Piaget, Constructivism

\section{Introduction}

Jean Piaget (1896-1980), while working with French psychologist Alfred Binet in the development of intelligence test, realized that children of similar ages gave same wrong answers. This initial experience gave him lifelong dedication to study genetic epistemology. Piaget's work was focused in cognitive development (Krogh \& Slentz, 2001; White \& Coleman, 2000).

Although Piaget did not study how children learn to read and write, other researchers and theorists have taken his basic theory and expanded upon it to investigate and explain literacy learning. Reading and writing, according to constructivist thinking, are representational systems that people use to communicate an almost limitless body of information, including thoughts, emotions, descriptions, and much more.

In Piaget's view, a child is born with certain genetic traits and as he/she develops interactions with the environment to construct his/her own intelligence. Piaget's view has been called "constructivism". Constructivism is not a theory about teaching, but a theory about knowledge and learning. It describes both what knowing is and how one comes to know. Constructivism shows that children acquire knowledge not by internalizing it directly from the outside but by constructing it from the inside, in interaction with the environment (Fosnot, 1996; Krogh \& Slentz, 2001; J. G. Brooks \& M. G. Brooks, 1993; Wadsworth, 1989).

\subsection{Constructivism}

Root of consructivism in education is usually consider as begin with Giambattista Vico's work De Antiquissima Italorum Sapientia published in 1710, in this study Vico argued that knowledge is something that is constructed by the learner (Cheek, 1992). In 1762, Rousseau published his famous book called Emile. In this book, Rousseau (2005) emphasized that all learning should drive from an environment in which students construct their own knowledge. The book discusses about how children learn by experience and draw their own conclusions and the role of the teacher is to stimulate students' curiosity. After Rousseau, Pestolazzi also supported the idea that children absorb knowledge through their own sensory experience and learning only occurs by doing (J. G. Brooks \& M. G. Brooks, 1993; Hodson, 2009).

Kant (1963) expanded upon this tradition by arguing that students are not passive recipients of information, instead, they actively construct their knowledge by connecting with their previous knowledge (as cited in Cheek, 1992). Following these researchers in 1950, John Dewey's work on how learners construct their own understanding using their prior knowledge were the leading educational studies. During 1960, Jerome Bruner supported the idea that children need assistance with their learning to build on what they already know (Cheek, 1992; Fosnot, 1989). David Ausubel (1968) remarked: "If I had to reduce all of educational psychology to just one single principle, I would say this: Find out what the learner already knows and teach him accordingly" (as cited in Hodson, 2009, p.337). 
Constructivism can be defined by the following four principles: 1. Knowledge consists of past constructions (prior knowledge); 2. Constructions come about through assimilation and accommodation. Assimilation refers to the logical framework or schema we used to understand or organize information. Accommodate is a higher-level theory or logic to take in the information; 3. Learning is an organic process of invention, rather than a mechanical process of accumulation. A constructivist takes the position that the learner must have experiences with hypothesizing and predicting, manipulating objects, posing questions, researching answers, imagining, investigating, and inventing, in order for new constructions to be developed; and 4. Meaningful learning occurs through reflection and resolution of cognitive conflict and thus serves to negate earlier, incomplete levels of understanding (Fosnot, 1989).

Although not a theory of teaching, constructivism is serving as the basis for many of the current reforms in education. Educators who base their practice on constructivism often hesitate to label or define their practice as constructivist teaching. J. G. Brooks and M. G. Brooks (1993) provided six principles of constructivist pedagogy: (a) learning is not the result of development, learning is development; (b) posing problems of emerging relevance to learners; (c) structuring learning is around a big ideas or primary concepts; (d) seeking and valuing students' points of view; (e) adapting curriculum to address students' suppositions; and (f) assessing student learning in the context of teaching (J. G. Brooks \& M. G. Brooks, 1993; Fosnot, 1996).

Piaget's theory is one of the most often used theories to explain how children learn and develop their thought process. Piaget believed that children adapt to the world around them. He used the word schema to explain cognitive process (Fosnot, 1996). A schema is a unit in human memory representing a functional package of knowledge. Schemata are important because they provide a way for infants and young children to organize the knowledge that they are always acquiring. According to Piaget, a schema includes three processes: assimilation accommodation, and equilibration (Wadsworth, 1989). Assimilation means that a child is taking in or understanding events in the environment. When the child comes across the different events, which he/she did not across with it, he/she makes sense of this experience based on his/her previous understandings. Accommodation is a process that is complementary to assimilation. In accommodation, a schema is changed to fit the new information. Equilibration is the balance between the adaptation processes of assimilation and accommodation. During the adaptation process, equilibrium helps the child create an understanding of the environment that makes sense. In other words, new experiences sometimes promote contradictions to our present understandings (Wadsworth, 1989; White \& Coleman, 2000; Brewer, 2001; Fosnot, 1996; Forman \& Kuschner, 1983; Stupiansky, 1997).
Consider, for example, a young girl whose only experience with water has been in a bathtub or a swimming pool. She experiences water as calm, moving only in response to the movements she made. Now think of this same child's first encounter with an ocean beach. She experiences the waves swelling and crashing onto the shore, whitecaps appearing then suddenly vanishing, and the ocean itself rolling and pitching in a regular rhythm. When some water seeps into her mouth, the taste is entirely different from her prior experiences with the taste of water. She is faced with a different experience of water; one that does not conform to her prior understanding. She must both actively construct a different understanding of water to accommodate her new experiences or ignore the new information and retain her original understanding (J. G. Brooks \& M. G. Brooks, 1993).

\subsection{Teacher's Role}

Constructivist teachers encourage and accept student independence and schema. They use raw data and primary sources, along with manipulative, interactive and physical materials. When framing task, constructivist teachers use cognitive terminology, such as classify, analyze, predict, and create. Constructivist teachers allow students' responses to drive lessons, shrift instructional strategies, and alter content; inquire about students' understandings of concepts before sharing their own understandings of those concepts; encourage students to engage in dialogue, both with the teacher and with one another; encourage student inquiry by asking thoughtful, open-ended questions and encourage students to ask questions of each other; seek explanation of students' initial responses; engage students in experiences that might produce constructions to their initial hypotheses and then encourage discussion; allow wait time after posing questions; provide time for students to construct relationships and create metaphors; and care for students' natural interest through frequent use of learning cycle model (J. G. Brooks \& M. G. Brooks, 1993; Roopnarine \& Johnson, 2000; White \& Coleman, 2000; Dixon-Kraus, 1996).

"For conceptual learning occur, first, learners must play an active role in selecting and defining the activities; second, there must be suitable teacher support as learners build concepts, values, schemata, and problem-solving abilities" (Fosnot, 1996, p.92). To make easy real learning, teachers need to organize their classroom and their curriculum so that students can collaborate, interact, and raise questions of both classmates and the teacher. Children's questions are important to help teachers understand developmental progression of children and how they understand literacy tasks.

\subsection{Student's Role}

The constructivist model views learners as vital in the process of learning language. Learners are active in seeking and constructing meaning and in seeking communication with others. Children learning language 
produce hypotheses and test them with the speaker in the environments. They try to combine sounds and words in different situations. Constructivists believe that this problem-solving behavior is very important in learning language. They also believe that the errors in children's speech reflect new knowledge about language rules. They also recognize the importance of social interactions in the development of language. For constructivists, many factors affect language learning, such as social, maturational, biological, cognitive, interactive, and modify one another as a child learns language. Many constructivist researchers believe that infants control much of their interaction with adults in their environments by smiling, making sounds, and repeating adult sounds to continue the interactions (Brewer, 2001).

\subsection{Construction of Literacy Based on Constructivism}

Piaget's work was focused on cognitive development of how children learn. The theory of cognitive development is characterized by the belief that children construct their own knowledge and understanding of the world through active exploration of their environments. Piaget asserted that thought comes before language and that language is a way of representing thought (Wadsworth, 1989). Piaget1964 divided cognitive development into four periods: sensorimotor, preoperational, concrete-operational, and formal-operational. According to Burns, Roe, and Ross (1999), Piaget's theory is based on the preoperational period. The preoperational period is divided into two stages, the preconception stage from age 2-4 and the intuitive stage from age 4-6/7). During the preconception stage, children begin to engage in symbolic thought by representing ideas and events with words and sentences, drawings, and dramatic play. As they begin to use symbols to stand for spoken words, they realize that writing represents meaning, a concept that is basic to reading comprehension. At the intuitive stage, children are rapidly developing concepts, but they are limited in their ability to use adult logic. They are egocentric, that is they consider things only from their own point of view. Not all children go through Piaget's stages at the same ages (White \& Coleman, 2000; Roopnarine \& Johnson, 2000; Forman \& Kuschner, 1983; Stupiansky, 1977).

Roopnarie and Johnson (2000) explained:

The constructivist has a strong commitment to the formal structure of knowledge which allows children to know with certainty that object $\mathrm{A}$ is a longer than object B without inspection. But constructivist teaching should not be relegated only to teaching the deductive structure of math, science, and logic. (p.160).

The constructivist approach does provide for attention to individual needs in which both the child and the teacher respond to ideas, concepts, and themes developed by others. It is more important to remember that Piaget's theory was developed and tested on white, middle-class children. Consequently, the constructivist approach reflects the major social values, attitudes, and customs (White \& Coleman 2000).

Piaget (1964) believed that many concepts that we so far had considered elementary, such as the concept of hidden, were actually extremely complicated and that we needed a new theory to explain how children younger than a year were able to learn such complicated concept (Roopnarine \& Johnson, 2000) such as the concept of hot can be learned only by experiencing it. We don't learn hot until we are burned (Brewer, 2001; Stupiansky, 1977).

The most important part of the constructivist model is instruction that focuses on the learners' active participation in constructing meaning rather than passive gaining of reading and composition skills and knowledge. A constructivist view of reading instruction would require providing good phonics instruction, so that they can construct systems of knowledge about letters, sounds, letter-sound relationships, and other conventions of English print. To constructivists, phonics instruction must always focus on individual children's needs and on information of interest to them, with the understanding that children will continue to develop literacy concepts over a long period of time. They will not master letter-sound relationship that does not make sense to them, no matter how often they are drilled. They may be able to provide an answer which their teacher wants to hear. But they will not be able to use the information when reading unless it fits into their own systems of understanding at that time (Brewer, 2001; Dixon -Kraus, 1996).

In the constructivist view, children are "reading" the first time when they bring meaning to print. Children are "writing" when they use marks to represent their ideas. When children correct their own errors, they learn more about the written language than they copy someone else's error-free models. Children do not absorb the meaning set in the written words; they must construct the meanings themselves in their own ways or in their own minds. Learning to read and learning to write are not linear processes that start with step one and proceed in an orderly, unchanging development that is common to all learners (Stupiansky, 1997).

There are five steps that learners go through as they develop spelling knowledge: 1 . Stage one is typical of the young preschoolers who have little understanding of what a word is; 2. Direct sound-to-letter characterize stage two that often observed in kindergartens. Bissex (1980) reported that while she was studying, her son failed repeatedly to get her attention and wrote the following message "AR Y DF" (Are you deaf?) (p. 3). Children at this stage are beginning to translate, but usually by instead of the most well known constant sounds; 3 . Children begin to add some vowels by stage three, but still with a direct sound-to-letter match. For example, "rain" may be misspelled to "ran", whereas "sit" is frequently misspelled to "set" because the short /I/ sound is similar to the name of the letter "e"; 4 . In stage four, children (7-12 years old) are beginning to consider patterns as sounds. "Car" begins to be spelled correctly, including the "a", 
instead of just "cr". The "ai" appears in "rain". Patterns usually missed are those where meaning is important, for example, where suffixes, such as "-ed", "-es", "-ing”, are added; 5. Stage five (10-18 years old) is characterized by analysis of words for their derivates and meaning (Fosnot, 1989).

Kamii, C. \& DeVries, R. (1980) summarized the developmental levels for children's literacy capability. There were three main developmental levels to explain children's written products. At first level children try to distinguish between writing and drawing. They realize the differences between their organizing styles. Then try to make sense a relationship between drawing and writing but still they are not able to discover difference in meaning. At this level children are satisfied with their own goals. However, at second level, the early goals are not enough for them. They start to wonder why some words have more letters than others. They try to control quantitative and qualitative variations at the same time. The third level corresponds to the phonetization of the written symbol. One of the most important written information is a child's own name. Thus, they can accept that given series of letters are necessary to say their names. At this level, they understand that similarity of sound implies similarity of letters, and vice versa.

Forman and Kuschner (1983) explained the language development using contrast between traditional method and constructivist method. When children are 2-3 years old, in traditional method, the teacher focuses on teaching vocabulary, using words that relate to pictures at hand, and giving children verbal instruction. When children are 4-5 years old, the teacher concentrates on encouraging communication between children and playing word games. On the other hand, the constructivist teacher emphasizes on responding to the child's request literally, so that he/she understands his/her own language when the child is 2-3 years old. When children are 4-5 years old, they are placed in group-one as listeners and the other as speakers- to improve language as a means of transforming the unknown.

The language support system is created for children. The support system is scaffolding that provides a framework and supports children until they have mastered language forms at a given level; the scaffolding is moved to a higher level when a child's language forms become more complex. Scaffolding is a temporary framework that assists children's growth. As a child develops, the scaffolding changes (Foster, 1996; Brewer, 2001).

For example, when a very young child in a highchair drops a cereal bowl to the floor, her parent says "Uh-oh". When the child has learned to say that phrase each time she drops something, the parent begins to say "Down" or "Gone" each time. As the child's language abilities increase, the parent begins to use longer sentences when something is dropped, such as "Please don't drop your cereal bowl on the floor". (Brewer, 2001, p. 242).

\subsection{Education Programs Based on Constructivism}

The goal of any constructivist program is to stimulate children in all areas of development. Physical development, social and emotional development, and cognitive development are all important. Language development and an emphasis on the process of learning are also important (Brewer, 2001; Forman \& Kuschner, 1983). DeVries and Zan (1995) explained that sociomoral atmosphere includes a child's relationship with his/her teacher, other children, and the rules. This atmosphere should be respected for children's values. Constructivism stands in contrast to the more deeply rooted ways of teaching that have long typified American classrooms. Traditionally, learning has been thought to be a mimetic activity, a process that involves students repeating,or miming . Constructivist teaching practices, on the other hand, help learners internalize, reshape, or transform new information. Transformation occurs through the creation of new understandings that result from the emergence of new cognitive structures. The constructivist viewpoint rests on the assumption that children mentally construct knowledge through reflection on their experiences. A child is an active architect of learning. This view of children's development constructs with the behaviorist view of a child as a passive receptor of knowledge, which is acquired through imitation and practice and is internalized through processes of reward and punishment (Roopnarie \& Johnson, 2000; J. G. Brooks \& M. G. Brooks, 1993).

DeVries and Zan (1995) pointed out the necessary moral aspects of schooling and described the teacher-child relationship in constructivist classrooms. They said:

The constructivist teachers respect children by upholding children's rights to their feelings, ideas and opinions. These teachers use their authority selectively and refrain from using power unnecessarily. In this way, they give children an opportunity to develop personalities characterized by self-confidence, respect for self and others, and active, inquiring, creative minds. (p. 11)

Despite their general similarities, the goals of different constructivist programs can vary. There are some programs based on Piaget's theory. In George Forman's program, the goals are to help children develop cognitively through activities selected specifically to help them with the ideas of correspondence, transformations, functional relations, and changing perspectives. The High/Scope program, developed by David Weikart, is known for emphasizing careful and systematic observations of children and for organizing the curriculum around key experiences. Key experiences have been identified in the categories of social and emotional development, movement and physical development, and cognitive development. The Bank Street Program grew out of the work of Lucy Sprague Mitchell, who had been a student of the most famous educator John Dewey. Mitchell began a school for young children in which play would be taken seriously_namely, a school, in which children could play and researchers could study them doing so in a 
naturalistic setting. The following principles are the framework of these programs: 1. Development involves changes in the way a person organizes experience and copes with the world; 2 . Individuals are never at a fixed point on a straight line of development; and 3. The child's sense of self is built up from his/her experiences with other people and with objects.

In recent years, Reggio Emilia schools of northern Italy have been influenced on the early childhood educators. These community preschools are based on the following principles: 1. All children construct their own learning and are capable of learning; 2 . The community is an important force in the school, providing both financial support and involvement with programs and children; 3. Collaboration, sharing, and personal relationships are valued; 4. The environment - the third teacher is important in motivating interest and encouraging creativity; and 5. Teachers consider themselves as learners and work with other teachers and parents (Brewer, 2001; Roopnarie \& Johnson, 2000).

Constructivist programs stress the importance of an environment that encourages children to make choices and to follow their play with peers. Learning centers with materials for art, block play, writing and drawing, dramatic play, and exploration with raw materials, such as dirt, sand, and water, are available for children to select both individual and group projects (Roopnaire \& Johnson, 2000).

In the constructivist model, group games are a central feature of the curriculum. Curricula are planned and learning experiences are selected to follow children's interests or expose them to new areas according to their interests. Many activities and experiences are selected to help children think about solutions to social as well as cognitive problems. Literacy is taught in the context of children's other activities, as they extend their language to reading and writing. Constructivist assumes that literacy skills are best learned within a context in which they can be applied.

Wellhousen and Kieff (2001) emphasized on block play. They explained that block play provides a basic foundation for promoting language and literacy learning. To build oral language development, they clarified three specific ways: 1 . Children playing together with blocks need to communicate with one another and sometimes with an adult; 2 . Children expand their vocabulary during block play; and 3 . Dramatizing provides opportunities for using rich language.

Kamii-DeVries constructivist approach (Kamii \& DeVries, 1980) is based on Piaget's theory. This constructivist orientation considers the development of social skills, personality, and self-esteem as critical to children's active involvement with their environments. The approach encourages cooperative activities for the purpose of respecting the feelings and rights of others and coordinating different points of view. Kamii-DeVries approach includes two mainly components - physically knowledge activities and group games (White \& Coleman, 2000; Brewer, 2001; Kamii \& DeVries, 1980).

There is another way to construct knowledge-museums. When museums try to present didactic lessons, children lose their connection with their own interests and cannot relate our answers to any significant question. However, constructivism assumes that knowledge cannot be given and didactic teaching is not powerful enough to lead to cognitive restructuring. Such exhibits tend to focus on the final product rather than on the process of learning. Children need rich learning environments that allow them to explore and develop their own thinking in great depth. The nature of museums visits is that two or more children can learn together. Such exhibits make a virtue out of a necessity by providing opportunities for the social construction of knowledge (Roopnarie \& Johnson, 2000).

According to Labbo (1996), during the story time, children make an interaction with each other especially in the kindergarten level. This view of literacy learning, which holds that literacy learning, social interaction, and cognitive development are woven together, is based on Vygotskian perspective.

\section{Conclusion}

Constructivism is one of the best described and studied learning theories in education. However, there is no single teaching and learning style, which works best for everyone. Different teaching and learning styles provide different kinds of information used for different purposes. Teachers can select their most appropriate teaching strategies to help students learn new concepts within the confines of their classroom environment.

\section{References}

[1] Bissex, G. L. (1980). Gyns at WRK: A Child Learns to Write and Read. Cambridge, M.A.: Harvard University Press.

[2] Brewer, J. A. (2001). Introduction to early childhood Education: Preschool through primary grades. Boston, M.A.: Allyn and Bacon.

[3] Brooks, J. G., \& Brooks, M. G. (1993). In search of understanding: The case for constructivist classrooms. Alexandria, V.A.: Association for Supervision and Curriculum Development.

[4] Burns, P. L., Roe, B. D., \& Ross, E. P. (1999). Teaching reading in today's elementary schools. Boston, M.A.: Houghton Mifflin Co.

[5] Cheek, D. (1992). Thinking constructively about science, technology, and society education. New York, N.Y.: State University of New York Press.

[6] DeVries, R., \& Zan, B. (1995). Creating a constructivist classroom atmosphere. Young Children, 51(11), 4-13.

[7] Dixon-Krauss, L. (1996). Vygotsky in the classroom: Mediated literacy instruction and assessment. White Plains, N.Y.: Longman.

[8] Forman, G. D., \& Kuschner, D. S. (1983). The child's construction of knowledge: piaget for teaching children. Montery, C. A.: Brooks/Cole Pub. Co.. 
[9] Fosnot, C. T. (1989). Enquiring teachers, enquiring learners: A constructivist approach for teaching. New York, N.Y.: Teachers College Press.

[10] Fosnot, C. T. (1996). Constructivism: Theory, perspectives, and practice. New York, N.Y: Teachers College Press.

[11] Hodson, D. (2009). Teaching and learning about science: Language, theories, methods, history, traditions and values. The Netherlands: Sense Publishers.

[12] Kamii, C., \& DeVries, R. (1980). Group games in early education: Implications of piaget's theory. Washington, D.C.: National Association for the education of Young Children.

[13] Krogh, S. L., \& Slentz, K. L. (2001). Early childhood education:Yesterday, Today, and Tomorrow. Mahwah, N.J.: L. Erlbaum Associates.

[14] Labbo, L. D. (1996). Beyond story time: A sociopsychological perspective on young children's opportunities for literacy development during story extension time. Journal of Literacy Research, 28(3), 405-428.

[15] Piaget, J. (1964). Part I: Cognitive development in children: Piaget development and learning. Journal of Research in Science Teaching, 2(3), 176-186.
[16] Roopnarine, J. L., \& Johnson, J. E. (2000). Approaches to early childhood education. Upper Saddle River, N.J.: Merrill.

[17] Rousseau, J. J. (2005). Emile: Bir çocuk büyüyor (U. Akgunduz, Trans.). Istanbul: Selis Kitapları. (Original work published 1762).

[18] Stupiansky, S. W. (1997). Building understanding Together: A Constructivist Approach to Early Childhood Education. Albany, N.Y.: Delmar Publishers.

[19] Wadsworth, B. J. (1989). Piaget's theory of cognitive and affective development. New York: Longman.

[20] Wellhousen, K., \& Kieff, J. (2001). A constructivist approach to block play in early childhood. Albany, N.Y.: Delmar/Thomson Learning

[21] White, C. S., \& Coleman, M. (2000). Early childhood education: Building a philosophy for teaching. Upper Saddle River, N. J.: Merrill. 